\title{
PENINGKATAN KEMANDIRIAN ANAK USIA PRASEKOLAH DENGAN PEMBERIAN PENGUKUH POSITIF
}

\author{
Novia Sinta Rochwidowati ${ }^{1}$, Rahma Widyana ${ }^{2}$ \\ ${ }^{12}$ Fakultas Psikologi, Universitas Mercu Buana Yogyakarta \\ ${ }^{1}$ noviasinta.r22@gmail.com \\ 2umifaqih4@yahoo.com
}

\begin{abstract}
Abstrak
Penelitian ini bertujuan untuk mengetahui pengaruh pemberian pengukuh positif untuk meningkatkan kemandirian pada anak usia prasekolah. Hipotesis yang diajukan adalah Ada pengaruh pemberian pengukuh positif terhadap peningkatan kemandirian anak usia prasekolah, kemandirian anak selama dan setelah mendapatkan intervensi pemberian pengukuh positif mengalami peningkatan dibandingkan sebelum pemberian intervensi. Metode penelitian yang digunakan adalah kasus tunggal dalam bentuk desain eksperimen A-B-A. Pengukuran pemberian pengukuh positif menggunakan behavior checklist, sedangkan analisis datanya menggunakan visual inpection, dengan didukung analisis kualitatif, dengan uji Intraclass Correlation $(\mathrm{ICC}=0,989)$ dengan Sig. $=0.000$. Hasil penelitian menunjukkan bahwa perilaku kemandirian subjek yang mendapatkan intervensi berupa pemberian pengukuh positif meningkat. Salah hal yang terungkap dari penelitian ini adalah ada sikap nrimo dari subjek, ketika salah satu pengukuh positif digantikan karena ketiadaan barang tersebut.
\end{abstract}

Kata kunci : pengukuh positif, kemandirian anak usia prasekolah

\section{INCREASED SELF-SUFFICIENCY OF PRESCHOOL AGE CHILDREN WITH THE GRANTING OF POSITIVE PENGUKUH}

\author{
Novia Sinta Rochwidowati ${ }^{1}$, Rahma Widyana ${ }^{2}$ \\ ${ }^{12}$ Fakulty of Psychology, University of Mercu Buana Yogyakarta \\ 1noviasinta.r22@gmail.com \\ 2umifaqih4@yahoo.com
}

\begin{abstract}
Childrens are the new generation of the nation that will face the development of the world changes through the skills and expertise acquired children through education. But in its development, there are still children who are less likely to have behavioral independence. To do their activities children tend to rely on others, especially parents. This study aims to determine the effect of giving positive reinforcement to increase independence of preschool age children. The hypothesis is that there is effect of giving positive reinforcement to increase independence of preschool age children. The child's independence during and after getting intervention of giving positive reinforcement has increased compared to prior to the intervention. The method used was a single case in the form of experimental design of A-B-A. Measurement of giving positive reinforcement used behavior checklist, while data analysis used visual inpection supported by qualitative analysis with the test of intra-class correlation ( $\mathrm{ICC}=0.989$ ) and Sig . $=0.000$. The result showed that the behavior of subject independence who gains the interventions of giving positive reinforcement increased. Things unfold from this research is nrimo there is an attitude of the subject, when one positive reinforcement was replaced because of the absence of such items.
\end{abstract}

Keywords: positive reinforcement, independence of preschool 


\section{PENDAHULUAN}

Anak adalah generasi baru bangsa yang akan menghadapi perubahan dan perkembangan dunia, melalui ketrampilan dan keahlian yang diperoleh anak melalui pendidikan (Arini, 2008). Pendidikan adalah proses pengembangan anak ke arah berpikir dan berperilaku menjadi lebih baik, serta dapat diperoleh melalui lingkungan sekolah dan terutama lingkungan keluarga.Masa prasekolah menurut Munandar (1992), merupakan masa-masa bermain. Pada tahap perkembangan anak usia prasekolah, anak mulai menguasai berbagai ketrampilan fisik, bahasa, dan anakpun mulai memiliki rasa percaya diri untuk mengekplorasi kemandiriannya (Hurlock, 1997).

Lamman dkk (2008) mengatakan bahwa kemandirian merupakan suatu kemampuan individu untuk mengatur dirinya sendiri dan tidak tergantung kepada orang lain. Kemandirian sudah mulai berkembang jauh sebelum mencapai tahap dewasa. Menurut Basri (2000), kemandirian bukanlah kemampuan yang dibawa anak sejak lahir, melainkan hasil dari proses belajar. Menurut Sudilarsih (2010), bahwa proses pembentukan kemandirian anak tersebut diawali dari lingkungan terdekat, yakni keluarga dan pengalaman yang diperoleh anak dari lingkungan disekitar luar rumah. Kemandirian anak usia prasekolah dapat berkembang dengan baik apabila anak diberikan kesempatan untuk mengembangkan potensi yang dimilikinya melalui latihan dan pemberian stimulus (Sudilarsih, 2010).

Kenyataan yang dijumpai di lapangan tidaklah demikian, berdasarkan hasil penelitian Suseno dan Irdawati (2011) dalam e-journal.akbid-purworejo dengan judul "Hubungan Antara Pola Asuh Orang Tua Dengan Kemandirian Anak Usia Prasekolah di Tk Aisyiyah Mendungan Sukoharjo" membuktikan bahwa dari 20 orang anak yang mandiri ada 16 (80\%), kurang mandiri sebesar 3 (15\%), dan yang masih tergantung ada 1 (5\%). Hal tersebut didukung dengan hasil pengamatan peneliti bahwa beberapa anak masih tergantung dengan lingkungan terutama dengan orangtuanya. Anak yang belum mandiri, tampak akan selalu membutuhkan pertolongan orang lain untuk membantu dirinya dalam menyelesaikan tugas. Hubungan sosial anak yang belum mandiri dengan teman sebanyanya akan terganggu, karena anak selalu mengharapkan orangtuanya untuk menungguinya bahkan anak tidak bersedia bermain dengan temannya. Di sisi lain, kesempatan yang kurang diberikan oleh orangtua terhadap anak berdampak pada kepercayaan diri anak dalam melakukan kegiatannya sendiri, dan ketidaksabaran orangtua akan membuat anak tidak memiliki kesempatan untuk belajar.

Hal tersebut dapat mengakibatkan anak tidak memperoleh kesempatan untuk 
mencoba belajar mandiri. Ketika seorang anak meminta sesuatu kemudian merengek dan ibu langsung memberikan apa yang diinginkan anak, maka anak belajar bahwa dengan merengek ia akan mendapatkan barang yang diinginkan. Hal tersebut berarti bahwa dengan merengek anak mendapatkan reward berupa barang yang diinginkan, dan hal tersebut secara otomatis menjadi pembelajaran pembentukan perilaku pada anak. Dijelaskan oleh hasil penelitian Yusuf dkk (2006), bahwa pengembangan model modifikasi perilaku melalui "continouos reinforcement dan partial reinforcement" dapat digunakan untuk mengatasi kebiasaan buruk anak dalam belajar, sehingga dapat meningkatkan prestasi belajar.

Berdasarkan hal tersebut di atas berarti bahwa dengan pemberian reward terhadap anak dapat meningkatkan atau memberikan peluang agar anak mengulang perilaku yang akan dibentuk. Martin \& Pear (2003) menyebutkan bahwa salah satu teknik pengubahan perilaku adalah melalui pengukuhan yakni proses dimana tingkah laku diperkuat oleh konsekuensi yang segera mengikuti tingkah laku tersebut. Menurut Purwanta (2012), saat sebuah tingkah laku mengalami pengukuhan maka tingkah laku tersebut akan cenderung muncul kembali pada masa mendatang. Purwanta (2012) membagi jenis-jenis pengukuhan (reinforcement), diantaranya; Pengukuh positif (positif reinforcement) adalah kejadian sebuah tingkah laku yang diikuti oleh penambahan stimulus atau peningkatan intensitas dari stimulus sehingga hasilnya dapat mengukuhan tingkah laku tersebut; dan Pengukuh negatif (negatif reinforcement) adalah kejadian sebuah tingkah laku diikuti oleh penghilangan stimulus atau penurunan intensitas stimulus yang hasilnya menguatkan tingkah laku tersebut.

Pengukuh positif adalah segala bentuk respon, baik yang bersifat verbal maupun nonverbal yang berfungsi sebagai penguatan dari suatu perilaku (Martin \& Pear, 2003). Pemberian pengukuh positif terhadap suatu perilaku yang akan dibentuk, akan berdampak pada pembentukan perilaku yang diinginkan. Dalam hal ini, dengan pemberian pengukuh positif, suatu perilaku mandiri yang akan dibentuk dapat diterapkan kepada anak, sehingga perilaku kemandirian anak usia prasekolah yang dibentuk akan muncul.

Berdasarkan uraian tersebut maka penelitian ini mengajukan rumusan masalah: Apakah pemberian pengukuh positif dapat meningkatkan kemandirian anak usia prasekolah?.

Penelitian ini peneliti memiliki tujuan untuk memberikan upaya eksperimen dengan pemberian pengukuh untuk meningkatkan dan/atau melatih kemandirian pada anak melalui pemberian pengukuh positif ataupun cara 
meningkatkan kemandirian anak namun tidak menggunakan pengukuh positif sebagai variabel independen bagi anak usia prasekolah. Peneliti berkeyakinan bahwa penelitian yang akan dilakukan peneliti berbeda dengan beberapa penelitian yang telah dilakukan beberapa peneliti yang pernah ada. Perbedaan terletak pada adanya intervensi peningkatan kemandirian anak usia prasekolah melalui pemberian pengukuh positif.

Manfaat yang ingin dicapai dalam penelitian ini bahwa dengan pemberian pengukuh positif maka kemandirian anak usia prasekolah dapat meningkat, sehingga anak mampu melakukan segala aktivitasnya sendiri tanpa bantuan/bergantung dari orang lain. Disisi lain, melalui pemberian pengukuh positif, anak akan belajar tentang perilaku yang baik bagi dirinya.

Brawer (Melatih kemandirian anak, 2008), bahwa kemandirian merupakan perilaku yang terdapat pada seseorang yang timbul karena dorongan dari dalam dirinya sendiri, bukan karena pengaruh orang lain. Hurlock (1997), menambahkan bahwa ketidakmandirian seorang anak identik dengan sikap bergantung yang terlalu berlebihan pada orang-orang disekitarnya.

Menurut Feist \& Feist (2008), anak yang mempunyai kemandirian rendah biasanya memiliki ciri khusus antara lain mencari bantuan, mencari perhatian, mencari pengarahan, dan mencari dukungan pada orang lain. Mengharapkan inisiatif anak yang tidak mandiri cukup sulit, karena anak-anak membutuhkan peran orang-orang di lingkungannya untuk mengambil inisiatif untuk dirinya (Coles dalam Hurlock, 1997). Biddulph \& Biddulph (2006), menambahkan, bahwa biasanya anak membutuhkan kedekatan secara fisik dengan orangtua atau pengasuhnya, dan tanda lain yang dapat muncul pada anak usia prasekolah yang sering bergantung pada orangtua adalah seringnya anak menangis ketika ditinggal sebentar oleh ibunya. Hal tersebut terkadang terbawa hingga akhir masa prasekolah sehingga menjadikan anak suka merengek serta sering melontarkan protes apabila menemui hal-hal yang tidak sesuai dengan keinginannya, anehnya orangtua terkadang merasa tidak cemas dengan sikap anak mereka yang tidak mandiri (Biddulph \& Biddulph, 2006).

Penelitian ini mengacu pada aspek kemandirian menurut Lamman, dkk (2008) membagi menjadi lima bagian, diantaranya; Kebebasan, yaitu dapat menentukan keinginan sendiri tanpa bergantung terhadap orang lain; Pengambilan kepustusan, yaitu kemampuan mengambil alternatif tindakan yang akan dilakukan; Kontrol diri, yaitu kemampuan menguasai emosi diri tanpa bantuan orang lain; Ketegasan diri (asertif), yaitu dapat menyampaikan 
suatu keinginan terhadap orang lain; Tanggungjawab, yaitu kemampuan dalam menyelesaikan tugas tanpa bantuan orang lain serta dapat menerima resiko atas kesalahan yang dilakukan. Berdasarkan aspek dari Lamman dkk tersebut, Sudilarsih (2010) membagi kemandirian menjadi 2, yakni kemandirian fisik dan kemandirian psikologis. Kemandirian fisik adalah kemampuan anak untuk mengurus dirinya sendiri, sedangkan kemandirian psikologis adalah kemampuan untuk membuat keputusan dan memecahkan masalah sendiri. Menurut Sudilarsih (2010) kemandirian anak secara fisik dapat terlihat dalam ciriciri perilaku, diantaranya anak dapat makan dan minum sendiri, anak mampu memakai pakaian dan sepatu sendiri, anak mampu merawat diri sendiri dalam hal mencuci tangan dan/atau anak mampu menggunakan toilet, mengambil/meletakkan sendiri alat tulis yang dibutuhkan, tidak menangis ketika ditinggal orangtua selama sekolah berlangsung, bermain bersama teman sebaya tanpa ditunggui, merapikan tas ketika akan akan pulang sekolah, dan anak dapat memilih kegiatan yang disukai seperti menari, menulis, menggambar, bermain boneka, serta anak tidak lagi ditunggui oleh orangtua atau pengasuhnya.

Rina (2008) menyatakan bahwa kemandirian anak bisa dilatih, dan sebagai orangtua sudah selayaknya mendidik anak, hingga tiba saatnya nanti anak mampu melakukan aktivitas tanpa bantuan dari orang lain. Lebih lanjut Basri (2000), menambahkan bahwa kemandirian anak dapat dibina semenjak anak masih usia dini dengan penanaman disiplin yang konsisten sehingga kemandirian yang dimiliki dapat berkembang secara utuh.

Menurut Hurlock (1997), bahwa ada beberapa faktor pendukung kemandirian anak; yakni dimana pada dasarnya anak akan tumbuh mandiri, apabila anak tersebut berada dalam lingkungan yang orang-orang di sekelilingnya mampu menciptakan faktor yang dapat mendukung anak untuk tumbuh berkembang dengan normal dan bahagia. Terbentuknya kemandirian bukanlah kemampuan yang dibawa anak sejak lahir, melainkan hasil dari proses belajar.

Menurut Sudilarsih (2010), alasan yang menyebabkan orangtua cenderung untuk memberikan bantuan dan perlindungan berlebihan, terbagi menjadi 2, yaitu karena orangtua merasa khawatir dan orangtua yang tidak sabar. Orangtua yang terlalu khawatir akan membatasi anak untuk mencoba kemampuannya. Apabila kekhawatiran dan perlindungan yang berlebihan berlanjut terus sejalan dengan bertambahnya usia anak, maka anak akan selalu mengharapkan bantuan orang lain setiap kali anak menghadapi masalah. Orangtua yang tidak sabar dalam memberikan kesempatan kepada anak 
untuk mencoba belajar. Orangtua cenderung lekas membantu anak agar cepat selesai daripada menunggu anak menyelesaikannya sendiri, sehingga dapat mengakibatkan anak tidak memperoleh kesempatan untuk mencoba belakar mandiri.

Soetjiningsih (1995) mengemukakan bahwa anak yang mendapatkan stimulasi yang tepat akan lebih cepat berkembang perilaku kemandiriannya daripada anak yang kurang atau bahkan tidak mendapatkan stimulasi. Pemberian stimulasi yang tepat untuk membentuk perilaku mandiri pada anak akan membuat anak belajar lebih cepat. Soetjiningsih (1995), menambahkan stimulasi dapat juga berfungsi sebagai pengukuh positif, bahwa pemberian pengukuh positif akan efektif apabila pemberian tersebut sesuai dengan kebutuhan dan keinginan anak. Hal ini didukung oleh hasil penelitian Magoon (2008) dalam Journal Experimental Analysis Behavior, membuktikan bahwa dengan pemberian hadiah (reward) dapat memunculkan perilaku yang diharapkan dan dapat menjadikan konsekuensi yang menyenangkan. Sebaliknya, dengan pemberian hukuman (punisment) dapat memberikan respon positif yakni tidak memunculkan perilaku yang diharapkan, namun bukan merupakan konsekuensi yang menyenangkan.

Arini (2006) menjelaskan bahwa adanya stimulasi "pemberian reward" saat anak mampu menyelesaikan tugasnya tanpa bantuan orang lain, dan perilaku ketidakmandirian anak juga dapat terbentuk pula dari hasil anak mendapatkan reward berupa bantuan segera ketika anak membutuhkan pertolongan. Hal tersebut mengakibatkan anak belajar bahwa ketika anak meminta sesuatu anak akan merengek ataupun menangis, sehingga reward akan langsung diberikan dengan segera. Sudilarsih (2010), menegaskan bahwa hasil belajar mandiri anak akan tampak, apabila orangtua rajin dan konsisten dalam memberikan stimulus yang sesuai agar meningkatkan pengulangan perilaku anak yang diinginkan.

Berdasarkan hal tersebut di atas berarti bahwa dengan pemberian reward terhadap anak dapat meningkatkan atau memberikan peluang agar anak mengulang perilaku yang akan dibentuk. Pemberian reward atau pengukuh positif sebagai salah satu bentuk stimulasi dan motivasi untuk anak agar dapat mempertahankan perilaku yang sudah ada atau membentuk perilaku baru yang diinginkan.

Martin \& Pear (2003)
mengemukakan bahwa perilaku adalah
segala sesuatu yang orang katakan atau
lakukan. Perilaku bentuk respon
seseorang terhadap suatu stimulus atau
keadaan yang terjadi. Perilaku dapat
dibentuk melalui pemberian stimulus
yang sesuai. Pengukuh positif merupakan InSight, Tahun XIII/Nomor 1/Februari 2016 
salah satu proses belajar perilaku, yang dilakukan dengan cara memodifikasi suatu bentuk perilaku yang akan diterapkan. Pemberian pengukuh positif memperkuat perilaku yang diinginkan, oleh karenanya langkah pertama dalam merencanakan adalah dengan mengidentifikasi dan mendefinisikan perilaku yang ingin diperkuat dan yang akan diberi penguatan (Soekadji, 1983).

Berdasarkan penjelasan di atas dapat disimpulkan bahwa kemandirian anak usia prasekolah adalah kemampuan anak dalam melakukan tugasnya sendiri tanpa adanya campur tangan orang lain. Kemandirian usia prasekolah dapat diartikan sebagai keterampilan untuk membantu diri sendiri, baik kemandirian secara fisik maupun kemandirian secara psikologis. Berdasarkan uraian tersebut dapat disimpulkan bahwa dalam melatih kemandirian anak dapat melalui berbagai tahap pemberian penguatan positif (positif reinforcement). Kemandirian anak dapat dilatih dan dibentuk melalui penerapan stimulus yang sesuai dan pemberian penguatan positif terhadap perkembangan perilaku mandiri anak.

Berdasarkan beberapa prinsip dasar penerapan perilaku, peneliti akan menggunakan prinsip dasar belajar berupa pemberian pengukuh (reinforcement). Pemberian penguatan (reinforcement) dilakukan ketika suatu perilaku (respon) diikuti oleh stimulus yang menguntungkan (biasanya dilihat sebagai stimulus yang menyenangkan) sehingga dapat meningkatkan frekuensi perilaku yang akan dibentuk. Martin \& Pear (2003) menambahkan bahwa dalam penerapan modifikasi perilaku, pengukuh tidak dibiarkan terjadi secara alamiah (natural consequence) tetapi diatur sedemikian rupa agar menjadi konsekuensi tindakan/perilaku yang ingin ditingkatkan atau dipelihara. Martin \& Pear, (2003) menambahkan bahwa dalam penerapan modifikasi perilaku, pengukuh tidak dibiarkan terjadi secara alamiah (natural consequence) tetapi diatur sedemikian rupa agar menjadi konsekuensi tindakan/perilaku yang ingin ditingkatkan atau dipelihara.

Pemberian pengukuh positif adalah salah satu cara untuk memberikan motivasi kepada subjek supaya bersedia melakukan perilaku kemandirian. Subjek yang awalnya tidak bersedia, secara tidak langsung akan menyenangkan, sehingga perilaku mandiri tersebut akan dimunculkan oleh subjek secara terus menerus (continue). pengukuh positif dapat mempengaruhi suatu perilaku yang akan dibentuk, ataupun untuk menguatkan perilaku yang akan dipertahankan. Pemberian pengukuh positif dapat melatih pembentukan kemandirian anak usia prasekolah, sehingga tingkat kemandirian anak dapat meningkat atau sesuai dengan tahap perkembangannya. Perilaku kemandirian anak dapat ditingkatkan melalui pemberian pengukuh positif, 
karena dengan pengukuh positif suatu perilaku dapat dibentuk dengan cara menyenangkan anak.

Menurut asumsi peneliti, bahwa perilaku kemandirian anak usia prasekolah yang ditunjukkan merupakan hasil pembinaan, bimbingan dan bentukan pendidikan serta pola asuh yang dikembangkan orang tua. Penciptaan lingkungan yang kondusif terhadap pembentukan kemandirian anak usia prasekolah, tidak akan lepas dari orang tua sebagai pemeran utama; secara umum konsep pemberian pengukuh positif dalam penelitian ini adalah meningkatkan motivasi terhadap anak agar dapat melakukan aktivitasnya dengan mandiri. Berbagai variasi dan tingkatan dalam pemberian pengukuh positif dapat meningkatkan perilaku kemandirian anak usia prasekolah sesuai tahap perkembangannya. Partisipasi aktif dari orangtua serta peran serta guru dapat memberikan pengaruh yang positif terhadap penerapan perilaku kemandirian anak menjadi lebih efektif.

Berdasarkan keterangan tersebut di atas, disimpulkan bahwa kemandirian merupakan salah satu tugas perkembangan anak yang harus dilalui, dimana anak akan belajar untuk membantu dirinya sendiri dan tidak bergantung terhadap orang lain. Disisi lain, minimnya kemandirian anak dapat mengakibatkan anak akan kesulitan dalam menyelesaikan tugas secara mandiri, serta akan selalu bergantung terhadap oranglain dalam setiap pengambilan keputusan dalam hidupnya. Kemandirian merupakan suatu perilaku yang dapat dikukuhkan atau dibentuk melalui pemberian pengukuh positif. Target perilaku yang akan dibentuk atau ditingkatkan dalam penelitian ini adalah kemandirian anak usia prasekolah yang belum memiliki perilaku mandiri sesuai dengan usia perkembangannya. Pemberian pengukuh positif dapat diasumsikan bahwa ada hubungan langsung antara konsekuensi perilaku yang akan ditingkatkan dan kemungkinan perilaku tersebut terulang, dalam hal ini yakni peningkatan kemandirian anak usia prasekolah. Usaha apapun untuk menjelaskan, memprediksi, dan mempengaruhi motivasi akan melibatkan kegiatan mengukur perilaku dan menguji konsekueni dari perilaku saat ini dan perilaku yang diinginkan.

Berdasarkan uraian di atas, hipotesis yang ingin dibuktikan dalam penelitian ini adalah bahwa ada pengaruh pemberian pengukuh positif terhadap peningkatan kemandirian anak usia prasekolah, kemandirian anak selama dan setelah mendapatkan intervensi pemberian pengukuh positif mengalami peningkatan dibandingkan sebelum pemberian intervensi.

\section{METODE}

Subjek dalam penelitian ini adalah anak usia prasekolah yang memiliki 
perilaku kemandirian rendah. Usia subjek adalah 5 tahun 8 bulan, dengan jenis kelami laki-laki, bersekolah di sebuah TK ABA di Yogyakarta. Desain penelitian yang digunakan adalah desain eksperimen kasus tunggal dalam bentuk desain eksperimen A-B-A. Desain eksperimen kasus tunggal dilakukan untuk mengetahui efek suatu perlakuan dengan jalan membandingkan kondisi atau performansi subjek dari waktu ke waktu dimana subyek diamati perilakunya pada keadaan tanpa perlakuan dan dengan perlakuan secara bergantian (Latipun, 2004).

Alasan peneliti menggunakan desain eksperimen kasus tunggal adalah baik sampel kelompok maupun subjek tunggal dianggap paling sesuai untuk penelitian ini, terutama karena perilaku yang diamati tidak mungkin diambil rata-ratanya. Alasan kedua peneliti menggunakan desain eksperimen kasus tunggal adalah faktor etis. Menurut Latipun (2004), desain pembanding sering bertentangan dengan landasan etis bahwa desain kelompok tradisional melibatkan kelompok kontrol yang tidak menerima perlakuan (treatment), yang seharusnya mereka juga berhak untuk memperoleh intervensi. Alasan ketiga adalah bahwa aplikasi dari suatu desain kelompok pembanding tidak mungkin dapat dijalankan dalam beberapa kasus sebab kecilnya ukuran populasi.

InSight, Tahun XIII/Nomor 1/Februari 2016
Manipulasi variabel bebas yang dilakukan dalam penelitian ini adalah dengan cara memberikan pengukuhan positif pada subjek eksperimen. Program pemberian pengukuh positif disusun dengan tujuan penelitian yang diuraikan dalam secara rinci dalam modul pemberian pengukuh positif. Kegiatan eksperimen akan diberikan selama tiga minggu, setiap seminggu selama 5 hari, dengan durasi waktu per hari lebih kurang selama 4 jam. Kegiatan eksperimen dibagi melalui empat tahapan.

Tahapan-tahapan dalam penelitian ini meliputi; Tahap I yaitu pengukuran awal dengan menggunakan behavior checklist. Tujuan dari pengukuran ini adalah untuk mengetahui perilaku awal (baseline) subjek. Behavior checklist dilakukan oleh tiga orang observer/pengamat yang akan memperhatikan perilaku-perilaku subjek yang muncul setiap saat kemudian dilakukan pencatatan; Tahap II yaitu pemberian informasi terhadap orangtua dan guru terkait tentang perilaku anak yang akan ditingkatkan, dan pembuatan kesepakatan dengan anak meliputi perilaku yang akan mendapatkan reward dan jenis/bentuk pengukuh positif (reward) yang diinginkan/dibutuhkan; tahap III berlangsung observer akan mengobservasi subjek selama 2 minggu berturut-turut. Tujuannya adalah untuk melihat perilaku-perilaku subjek yang dimunculkan selama pemberian intervensi dan melakukan pencatatan. Selain itu, 
untuk mengetahui apakah pemberian pengukuh sesuai dengan perilaku yang muncul, serta perilaku subjek ketika menerima pengukuh positif; Tahap IV yaitu sesi pengukuran akhir dengan behavior checklist, dimana subjek akan kembali diukur untuk melihat (baseline) dari perilaku akhir setelah pemberian pengukuh positif (intervensi). Behavior checklist dilakukan oleh tiga orang observer yang akan memperhatikan perilaku-perilaku subjek yang muncul setiap saat. Subjek akan diobservasi ketika berada disekolah, selama 5 hari.

Metode pengukuran dalam penelitian ini dilakukan dengan menggunakan observasi menggunakan lembar rating kemampuan motorik yang mengacu pada rating scale dan metode observasi sistematik (Hadi, 2004). Alat yang digunakan untuk pengumpulan data berupa Skala rating behavior checklist, yakni dengan cara mengobservasi perilaku subjek Observasi dengan menggunakan skala pengukuran (meansurement scales), berfungsi untuk melihat berbagai tingkat perilaku yang diukur (Shaughnessy dkk, 2007). Dalam penelitian ini, peneliti akan menggunakan pengamatan perilaku berupa checklist untuk merekam perilaku kemandirian anak.

Berdasarkan ciri kemandirian anak dari Sudilarsih (2010), peneliti menyusun item behavior checklist. Behavior checklist kemandirian anak data penelitian ini disajikan dalam bentuk indikator perilaku kemandirian yang akan diisi oleh pengamat (observer) dengan mencontreng perilaku yang muncul. Behavior checklist disajikan sebagai alat ukur perilaku kemandirian pada anak (subjek).

Tabel 1. Indikator dan Target Perilaku dalam behavior checklist.

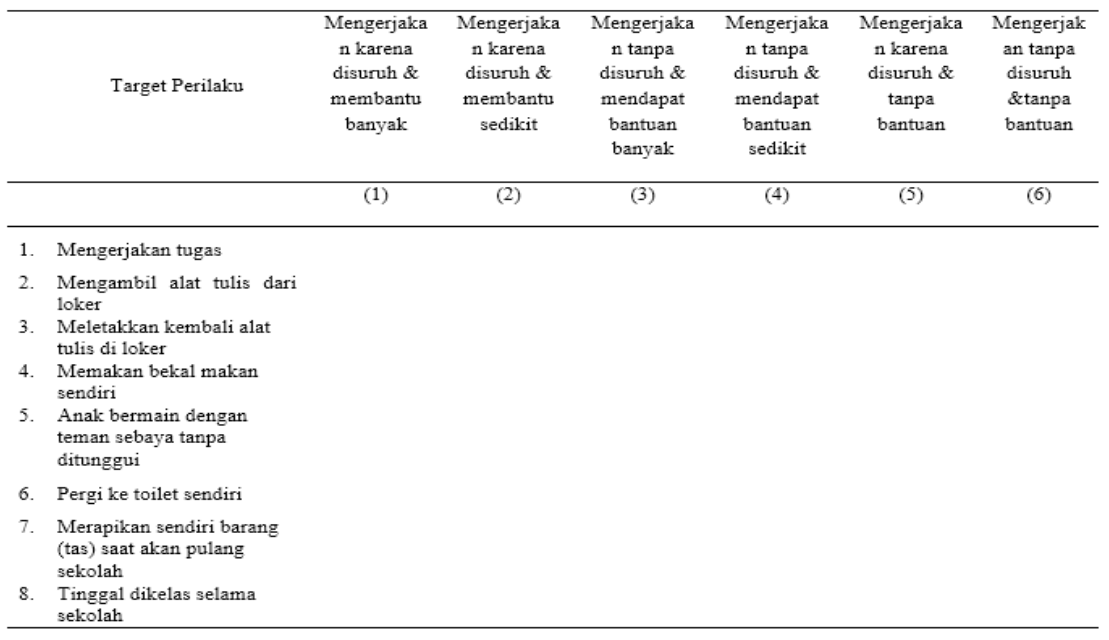

Penelitian dilaksanakan selama 4 minggu, di sebuah TK ABA di
Yogyakarta.. Sesuai dengan etika penelitian yang menggunakan subjek 
penelitian, subjek diberikan informed

consent. Lembar informed consent penelitian berisikan kesediaan orangtua/wali subjek sebagai wali anak (subjek) sebagai penanggungjawab subjek untuk mengikuti semua prosedur penelitian. Menentukan 3 orang observer/rater yakni seorang yang dapat bersikap objektif yang telah memiliki pengalaman dalam melalukan observasi dan 1 orang untuk memberikan pengukuh positif kepada subjek. Observer/rater bertugas sebagai pencatat hasil-hasil yang perlu diamati dengan seksama pada diri subjek sesuai dengan panduan observasi yang ada. Kemudian melakukan pengukuran terhadap subjek penelitian.

Berdasarkan hasil analisis ketiga rater dikatakan ICC-konsistesnsi nilainya yaitu $(\mathrm{ICC}=0.989)$, $\mathrm{Sig}=.000$ yang berarti bahwa hasil dari penilaian rater 1 , penilaian rater 2 dan penilaian rater 3 berkorelasi satu sama lain atau bersifat identik. Alat pendukung dalam pengumpulan data adalah dengan wawancara yang dikenakan pada orang tua subjek dan guru subjek. Peneliti akan menggunakan wawancara tertutup sebagai salah satu penggalian data. Menurut Prawitasari (2011) mengartikan wawancara tertutup adalah wawancara berupa pertanyaan dengan jawaban tertentu atau sudah ditentukan. Wawancara dilakukan sebelum dan setelah diberikan intervensi pengukuh positif. Dalam penelitian ini, wawancara yang diberikan kepada orangtua dan guru berupa pertanyaan tertutup yang disusun berdasarkan aspek-aspek kemandirian menurut Lamman dkk (2008) dan ciri-ciri perilaku kemandirian menurut Sudilarsih (2010). Pedoman wawancara terkait informasi tentang perilaku kemandirian subjek selama di rumah dengan keluarga, tercantum dalam tabel 2 berikut;

\section{Tabel 2 Pedoman Wawancara}

\begin{tabular}{|c|c|c|}
\hline & & Pedoman Wawancara \\
\hline $\begin{array}{l}\text { Menggali } \\
\text { informasi } \\
\text { kepada } \\
\text { guru }\end{array}$ & $\begin{array}{l}\text { Bagaimana latar } \\
\text { belakang subjek } \\
\text { serta aktivitasnya } \\
\text { selama di sekolah }\end{array}$ & $\begin{array}{l}\text { 1. Kondisi keluarga dan latar belakang subjek } \\
\text { 2. Apakah orangtua subjek mendukung penuh setiap } \\
\text { aktivitas subjek selama berada di sekolah } \\
\text { 3. Apakah subjek termasuk anak yang mudah menerima } \\
\text { informasi yang disampaikan oleh guru serta } \\
\text { bagaimana rentang konsentrasi subjek selama di } \\
\text { dalam kelas } \\
\text { 4. Sejauhmana tingkat kemandirian subjek dalam } \\
\text { melakukan aktivitas pribadinya, contoh ketika hendak } \\
\text { ke kamar mandi (mandi, buang air besar / buang air } \\
\text { kecil mencuci tangan), melepaskan dan/atau } \\
\text { melepaskan sepatu, mengambil atau meletakkan alat }\end{array}$ \\
\hline
\end{tabular}


tulis, dan lain sebagainya.

5. Sejauhmana tingkat kemandirian subjek dalam melakukan dan menyelesaikan tugasnya sesuai instruksi guru.

\begin{tabular}{|c|c|c|c|}
\hline Menggali & Menggali informasi & 1 & Menggali informasi bagaimana perkembangan subjek \\
\hline informasi & tentang kegiatan & 2 & Bagaimana pola kemandirian subjek selama berada di \\
\hline kepada & selama & & rumah \\
\hline orangtua & berada di rumah & 3 & Apakah subjek sudah mampu melakukan kegiatan \\
\hline & kepada orangtua & & pribadinya sendiri seperti bersih diri yakni, mandi, \\
\hline & & & buang air besar/kecil, makan tanpa disuapi, memakai \\
\hline & & & atau melepaskan sepatu dan lain sebagainya. \\
\hline
\end{tabular}

Uji coba alat ukur "behavior checklist" dan modul "kemandirian anak" untuk menguji validitas dan reliabilitas alat ukur sebelum digunakan dalam penelitian. Behavior checklist diujicobakan kepada siswa Taman Kanakkanak yang memiliki kesamaan karakteristik dengan subjek penelitian. Dari hasil uji coba alat ukur tersebut dapat dilihat bahwa alat yang digunakan dapat mengukur perilaku kemandirian anak, serta dapat digunakan untuk dijadikan sebagai alat ukur pada penelitian sebenarnya.

Teknik analisis data yang digunakan dalam penelitian ini dilakukan secara kuantitatif yaitu dengan menggunakan metode visual inpection Secara objektif akan ditampilkan gambar berdasarkan skor total rerata kemandirian dari ketiga rater. Visual inpection bertujuan untuk mendapatkan suatu informasi data subjek yang nantinya dipersentasekan sebagai hasil dari pemberian pengukuhan positif yang dijalankan oleh subjek. Dengan menggunakan grafik sebagai suatu gambaran pelaksanaan eksperimen baik sebelum, selama pemberian pengukuh positif maupun sesudah diberikan pengukuh positif. Data didukung dengan data kualitatif berdasarkan catatan hasil observasi dari ketiga rater lapangan, dan hasil wawancara dengan guru wali kelas dan orangtua subjek.

\section{HASIL DAN PEMBAHASAN}

Berdasarkan data mentah dari ketiga hasil pengukuran sebelum intervensi (Fase A1), selama pemberian intervensi pengukuh positif (Fase B), dan setelah pemberian intervensi (Fase A2), maka dapat dicari rerata skor total dari ketiga rater. Berikut ini analisis data yang dihasilkan dari skala rating yang ditampilkan dalam bentuk grafik. Setiap grafik mewakili rerata skor total dari ketiga rater berdasarkan tingkat periaku kemandirian anak saat pretest (baseline awal/fase A1), selama pemberian 
perlakuan/intervensi pengukuh positif

(fase B) dan posttest (baseline akhir/fase
A2) yakni setelah diberikan pengukuh positif selama 5 hari.

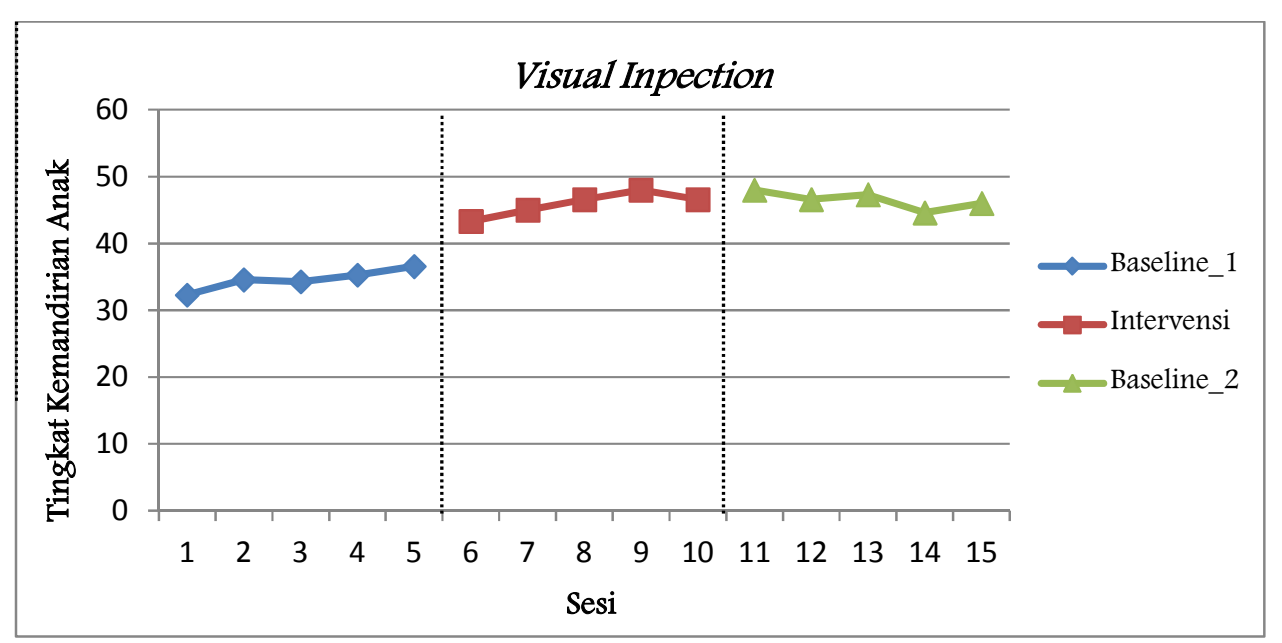

Gambar 1. Grafik 1 Analisis data rater_1,2,3

Berdasarkan hasil visual inspection dari skor total rerata ketiga rater dapat disimpulkan bahwa adanya peningkatan perilaku kemandirian subjek dari sebelum, selama pemberian pengukuh positif, dan setelah diberikannya intervensi pengukuh positif. Secara analisis data statistik (visual inpection) dan analisis kuantitatif dapat disimpulkan bahwa hasil dari kedua analisis menunjukkan adanya pengaruh pemberian pengukuh positif pada subjek dengan tingkat kemandirian rendah, hal tersebut dapat dilihat dari hasil visual inspection skala rating (F) subjek terjadi perubahan, baik dari rater 1 , rater2, dan rater 3 .

Berdasarkan hasil wawancara yang dilakukan kepada guru kelas subjek, secara akademik subjek sebenarnya sudah cukup mampu mengikuti tugas yang diberikan oleh guru, misalnya menirukan menulis huruf dan angka, subjek juga mampu melakukan aktivitas lain seperti menggunting, melipat meskipun belum rapi. Subjek tidak mau ditinggal oleh ibunya, dan ibu harus menunggui subjek selama di sekolah, bahkan duduk di sebelah subjek. Setiap mengerjakan tugas yang diberikan oleh guru subjek awalnya mau mengerjakan sendiri, namun seringkali tampak meminta bantuan dari ibunya, bahkan terkadang ibunya sendiri yang langsung membantu subjek tanpa diminta. Ibunya kurang memberikan kesempatan subjek, sehingga membuat anak kurang memiliki kepercayaan untuk melakukan kegiatannya sendiri, dan ketidaksabaran ibunya akan membuat anak tidak memiliki kesempatan untuk belajar

Selama pemberian intervensi dan setelahnya, guru menyampaikan bahwa 
ada perubahan pada diri subjek, tampak sekali subjek bisa aktif dalam kelas meskipun tanpa ibunya. Subjek mulai bersedia mengikuti kegiatan di sekolah tanpa ditemani dan ditunggui ibunya. Subjek mulai bermain dengan temantemannya tanpa harus ditunggui. Demikian pula dengan ibu subjek mengatakan bahwa selama dan setelah pemberian pengukuh positif, subjek mulai belajar melakukan semua aktivitasnya sendiri tanpa bantuan darinya. Bahkan saat ini subjek sudah tidak lagi ditunggui, meskipun awalnya sulit untuk meninggalkan selama di sekolah, namun setelah dibujuk dan diberi hadiah subjek akhirnya mau mengikuti semua kegiatan sekolah tanpa harus ditemani oleh ibunya. Menurut pengakuan ibunya bahwa perilaku subjek di rumah juga mulai ada perubahan; seperti mulai melakukan aktivitasnya tanpa harus ditemani ibu atau ayahnya dan belajar melakukannya sendiri, meskipun sedikit-sedikit masih perlu bantuan. Hal ini didukung oleh hasil penelitian Anastasia (2004), membuktikan bahwa pola asuh orangtua sangat berhubungan erat dengan pembentukan kemandirian untuk anak-anak. Hasil penelitian Hartinah (2009) juga menunjukkan bahwa ada pengaruh pemberian reward untuk mengurangi perilaku yang impulsif, bahkan menjadi konsekuensi yang menyenangkan bagi anak.
Berdasarkan hasil visual inpection dari grafik serta didukung oleh hasil wawancara dengan orangtua juga guru wali kelas, bahwa subjek dalam penelitian ini memperlihatkan bahwa adanya peningkatan perilaku kemandirian anak antara sebelum, selama pemberian pengukuh positif dan sesudah pemberian pengukuh positif. Hal tersebut dapat diartikan bahwa hipotesis yang diajukan dalam penelitian ini dapat diterima. Penelitian ini menunjukkan bahwa intervensi dengan pemberian pengukuh positif cukup dapat merubah maupun mempertahankan perilaku kemandirian pada anak usia prasekolah.

Pemberian pengukuh positif memberi kesempatan pada anak untuk belajar melakukan kegiatan/aktivitas dan tanggungjawabnya sendiri tanpa bantuan dari orang lain. Intervensi pemberian pengukuh positif memberikan rasa senang, menciptakan suasana yang santai tanpa paksaan, melibatkan emosi dan dapat mensimulasi dinamika perkembangan anak secara baik dalam meningkatkan pengetahuan dan pengalaman, sehingga mengalami perubahan perilaku kemandirian sesuai dengan masa perkembangannya. Menurut Soetjiningsih (1995), anak yang mendapatkan stimulasi akan lebih cepat berkembang daripada anak yang kurang atau bahkan tidak mendapatkan stimulasi. Lebih lanjut dijelaskan Soetjiningsih (1995), bahwa stimulasi dapat juga 
berfungsi sebagai pengukuh positif.

Penelitian ini dapat membuktikan bahwa intervensi dengan pemberian pengukuh positif dapat meningkatkan perilaku kemandirian anak usia prasekolah.

Berdasarkan uraian tersebut di atas dapat disimpulkan bahwa lingkungan yang mendukung meningkatnya perilaku kemandirian anak perlu diciptakan dan dikembangkan, baik dalam lingkungan keluarga, maupun di lingkungan sekolah. Salah satu cara yang dapat dilakukan adalah dengan memberikan pengukuh positif berupa pujian karena secara tidak langsung anak mendapatkan motivasi dan penghargaan vahwa apa yang dilakukannya adalah hal yang benar, dapat belajar dari pengalaman, serta dapat merubah sikap dan perilaku kemandiriannya.

\section{KESIMPULAN}

Berdasarkan hasil penelitian pada seorang siswa Taman Kanak-kanak di Yogyakarta, diperoleh bahwa terdapat peningkatan skor perilaku kemandirian anak sebelum perlakuan dan sesudah perlakuan. Hal tersebut berarti bahwa subjek mengalami peningkatan perilaku kemandirian. Ada pengaruh pemberian pengukuh positif terhadap peningkatan kemandirian anak usia prasekolah. Pengaruh pemberian pengukuh positif dapat bersifar menetap, hal ini menunjukkan bahwa intervensi pemberian pengukuh positif (reward) dapat merubah perilaku subjek menjadi lebih mandiri. Berdasarkan hasil penelitian menunjukkan adanya perbedaan perilaku pada anak sebelum, selama dan setelah pemberian pengukuh positif. Oleh karenanya dengan hasil ini disarankan bagi pihak sekolah bahwa dengan pemberian pengukuh positif dapat direkomendasikan sebagi salah satu alternatif untuk meningkatkan perilaku kemandirian pada siswa lain yang memiliki kecenderungan perilaku kemandiriannya belum terbentuk.

Perilaku kemandirian subjek mengalami peningkatan, namun hal tersebut harus tetap dipertahankan oleh subjek dengan cara orangtua (wali) subjek tetap memberikan pengukuh positif berupa pengukuh sosial terhadap perilakuperilaku mandiri yang telah dibentuk. Oleh karenanya, subjek dalam melakukan aktivitasnya tidak lagi bergantung pada orangtua ataupun oranglain. Dalam penelitian ini terdapat beberapa kelemahan yang menyangkut proses penelitian, sehingga dalam pelaksaannya terdapat kelemahan. Oleh karena itu, kepada peneliti selanjutnya diharapkan untuk dapat mengembangkan intervensi pemberian pengukuh positif ini sehingga dalam pelaksanaan lebih sempurna dan mudah diterima oleh anak.

Bagi peneliti selanjutnya yang tertarik untuk meneliti intervensi ini, disarankan untuk menambah jumlah subjek, karena setiap subjek akan berbeda dalam karakteristik tingkat kemandiriannya. 
Peneliti selanjutnya disarankan untuk benar-benar memahami cara penentuan jadwal sebelum pelaksanaan pemberian intervensi ini, sehingga tidak ada kekeliruan dalam menentukan skor subjek pada saat baseline dan memahami bentuk pengukuh positif (reward) yang akan diberikan kepada subjek.

Peneliti selanjutnya diharapkan dapat memberikan follow-up berjenjang terhadap intervensi pemberian pengukuh positif yang telah dikenakan, sehingga perubahan target perilaku yang akan diubah/dibentuk dapat bertahan lama dan menjadi perilaku yang menetap bukan hanya sementara (temporer). Serta perlunya memberikan kontrol terhadap variabel lain yang diduga dapat mempengaruhi hasil penelitian, sepert jenis kelamin, faktor ekonomi, dan faktor personal lainnya.

\section{DAFTAR PUSTAKA}

American Psyichology Association. (2002). Publication Manual Of The American Psychological Association (Sixth Ed.). Washington D.C. : APA.

Anastasia (2004). Hubungan Pola Asuh Orangtua Dengan Kemandirian Anak TK Pangudi Luhur Bernadus Semarang. Diunduh dari Http://www.google.kemandirian anak-pendidik.com. pada 25 Februari 2012.

Arini, AT. (2006). Melatih Anak Jadi Mandiri, dalam Pustaka Familia. "Membuat Prioritas, Melatih Anak Mandiri" (hlm. 17-22). Yogyakarta : Kanisius.
Basri, H. (2000). Remaja Berkualitas. Yogyakarta: Pustaka Pelajar Offset.

Barlow, D.H. \& Hersen, M. (1984). Single-Case Experimental Design : Strategics For Studiying Behavior Change (2nd Ed.) New York : Pergamon Press.

Biddulph, S \& Biddulph, S. (2006). Mendidik Anak Dengan Cinta. PT. Gramedia Jakarta : Pustaka Utama.

Bouxsein, K.J., Roane, H.S., \& Harper, T. (2011). Evaluating The Separate And Combined Effects Of Positive And Negative Reinforcement On Task Compliance. Diunduh dari Journal Application Behavior Analyses. Spring; $\quad 44(1)$ : 175-179. PMCID:PMC 3050464. Doi: 10.1901/jaba.2011.44-175.

Catania, A.C. (2001). "Positive Psychology and Positive Reinforcement". Diunduh dari Journal Of The American Psychological Association. Vol.56. Doi : 10.1037//0003-066X.56.1.86.

Catania, A.C. (2008). Reinforcement schedules: Retroactive and proactive effects of reinforcers inserted into fixed-interval performances. Diunduh dari Journal Experimental Analysis Behavior. 2008 January; 89(1): 111-118 : PMCID:PMC $2211432 . \quad$ Doi: 10.1901/jeab.2008.89-111.

Chaplin, J. (2005). Kamus Lengkap Psikologi. PT Raja Grafindo Persada. Jakarta.

Feist, J. \& Feist, G. (2008). Theories of Personality - edisi keenam. Yogyakarta : Pustaka Pelajar.

Gamayanti, IL., (2006). Menjadi mandiri dengan pekerjaan sehari-hari, dalam

InSight, Tahun XIII/Nomor 1/Februari 2016 
Pustaka Familia. "Membuat Prioritas, Melatih Anak Mandiri" (hlm. 55-61). Yogyakarta : Kanisius.

Hartinah. (2009). Pengaruh Pemberian Reward Dan Punishment Untuk Mengurangi Perilaku Attention Deficit Hyperaktivity Dissoder (ADHD). Diunduh dari Http://google.pengaruhpemberianreward.com pada 2 Mei 2011.

Hurlock, E.B. (1997). Psikologi Perkembangan - Suatu Pendekatan Sepanjang Rentang Kehidupan. Jakarta : Erlangga.

Lamman, dkk. 2008. "Faktor Genetik Pegang Peranan Dalam Kemandirian Anak”. Diunduh dari Http://google.kemandirian anak.com, pada 7 Maret 2010.

Latipun, (2004). Psikologi Eksperimen. Malang : Universitas Muhamadiyah Malang Press.

Magoon, M.A. (2008). Concurrent Schedules of Positive and Negative Reinforcement: Differential-Impact and Differential-Outcomes Hypotheses. Diunduh dari Journal Experimental Analysis Behavior. Auburn University : 2008 July; 90(1): 1-22. PMCID: PMC2441574. Doi: 10.1901/jeab.2008.90-1

Martin, G \& Pear, J. (2003). Behavior Modification : What It Is and How To Do it - four edition. New Jersey; Prentice Hall, Inc.

Morgan, D.L. \& Morgan, R.K. (2009). Single-Case Research Metodhs For The Behavioral And Health Sciences. United States of America : Sage Publications Inc.

Prawitasari, J.E. (2011). Psikologi Klinis - Pengantar Terapan Mikro \& Makro. Yogyakarta : Erlangga.
Sarafino, E.P. (2001). Behaviour Modification : Understanding Principles Of Behavior Change (eds. 2) London: Mayfield Publising Company.

Shaughnessy, J., Zechmeister, E., \& Zechmeister J. (2007). Metodologi Penelitian Psikologi (eds. 7). Yogyakarta : Pustaka Pelajar.

Soetjiningsih. (1995). Tumbuh Kembang Anak. Jakarta : ECG.

Sudilarsih, F. (2010). Mampu Mengatasi 1001 : Masalah Batita Anda Seharihari. Yogyakarta : Garailmu.

Suseno, D.D. \& Irdawati (2011). "Hubungan Antara Pola Asuh Orang Tua Dengan Kemandirian Anak Usia Prasekolah di Tk Aisyiyah Mendungan Sukoharjo”. Diunduh pada tanggal 30 Maret 2013, dari http://e-journal.akbidpurworejo.ac.id/index.php/jkk4/articl e/view/61/0.

Yusuf, dkk (2006). Pengembangan Model Modifikasi Perilaku Melalui Continous Reinforcement Dan Partial Reinforcement Untuk Mengatasi Kebiasaan Buruk Anak Dalam Belajar. Diunduh pada 28 Januari 2011, dari Http://jurnal.dikti.go.id/jurnal/detil/i d/24. 